\title{
EFFECT OF SALICYLIC ACID APPLICATION ON THE GROWTH AND ACTIVE CONSTITUENTS OF FENNEL PLANTS UNDER SALINITY STRESS CONDITIONS
}

\author{
M.M. Moussa ${ }^{(1)}$ and E.A. Abou Hussien ${ }^{(2)}$ \\ (1) Horticulture Dept., Fac. of Agric., Menoufia Univ., Shebin El-Kom, Egypt.
}

(2) Soil Sci. Dept., Fac. of Agric., Menoufia Univ., Shebin El-Kom, Egypt.

Received: Mar. 14, 2018

Accepted: Mar. 22, 2018

\begin{abstract}
Nowadays, Egypt faces a problem in the amount of available irrigation water because the Egyptian water quota is fixed, thus the cornerstone of the current Egyptian strategy is increasing crop productivity from unit area with the lowest possible amount of irrigation water. So, a pots experiment was carried out at the Experimental Farm, Faculty of Agriculture, Menoufia University, Shebin El-Kom, Egypt $\left(30.52^{\circ} \mathrm{N}\right.$ and $30.99^{\circ} \mathrm{E}$ ) during two successive growth winter seasons, i.e. 2013/2014 and 2014/2015 to study the effect of different rates of salicylic acid (SA), different salinity levels of irrigation water and their interactions on growth, yield and chemical compositions of fennel plants (Foeniculum vulgare, Mill.), variety of purple-bronze foliage grown on clayey-textured soil. SA was added as foliar applications at four rates namely 50, 100, 150 and 200 (mg/l) in addition to control treatment with SA-free water. The water used for irrigation (artificial water) has EC of 3, 5 and $7\left(d S \mathrm{~m}^{-1}\right)$ for W2, W3 and W4 respectively, beside Nile water (W1) which is characterized by EC of $0.37 \mathrm{dSm}^{-1}$. The design of the experiment is a complete randomized block with three replicates.

In two growing seasons, a vegetative growth characters, i.e. plant height (cm), number of main branches/plant and fresh weight of whole plant $(g)$ as well as yield parameters, i.e. number of umbels/plant, fresh and dry weights of umbels/plant (g), weight of 100 fruits (g/plant) and fruit yield (g/plant), chemical composition together with volatile oil percentage, oil constituents, photosynthetic pigments, $N, P, K$ and total carbohydrate contents were estimated of fennel plants. The obtained results indicated that, all vegetative growth characters and yield parameters were significantly reduced with increasing salinity levels of irrigation water, excluding those irrigated by W2 level, in which slight increments in all of studied criteria were induced. Also, chlorophyll $a$ and $b$ contents followed the same order, where the highest decrease in values was observed in plants irrigated by W4 level either individually or together with SA compared to control treatment. Contents (\%) of $N, P$ and $K$ were reduced with increasing salinity levels. While carotenoids, volatile oil and total carbohydrate contents (\%) were gradually increased with increasing salinity levels, especially in those irrigated by W3 level. Foliar spraying with different SA concentrations could have alleviated the harmful effect of salinity stress and was associated with high significant values in the most traits under study. Interactions between salinity levels of irrigation water and SA concentrations appeared to be the most effective on growth and yield parameters especially when fennel plants irrigated with W2 level and spraying with SA at $150 \mathrm{mg} / \mathrm{l}$.

Generally, the results of this study concluded that, under-irrigation by using saline water, salicylic acid should be used as foliar application especially at rate $150 \mathrm{mg} / \mathrm{l}$ to reduce the hazardous effects of irrigation water salinity on both quantity and quality of fennel plants.
\end{abstract}

Key words: Salicylic acid, Irrigation water salinity, Fennel plant, Growth parameters and chemical composition. 


\section{INTRODUCTION}

Fennel (Foeniculum vulgare, Mill.) is a highly flavorful and aromatic plant which belongs to the Family Umbelliferae (Apiaceae). It is one of the oldest and most important field crop used by the Egyptian as a remedy. In Egypt, fennel plants are mostly cultivated in midsouthern regions, mainly, Menoufia; ElFayom; Menia and Assiut Governorates.

Mature fennel fruits are considered
the main product of economic
importance of fennel, which contain
essential oil and are used as flavoring
agents in many food products including
liqueurs, bread, pickles, pastries, and
cheese. Moreover, the fruits can be used
as a stimulant to promote milk flow
during breast-feeding and to induce
menstruation (Rahimi and Ardekani,
2013). Also, fennel is used for several
medicinal purposes such as a
carminative, aromatic, diuretic, anti-
inflammatory, antimicrobial,
galactogogue and estrogenic activities
(Choi and Hwang, 2004). The volatile oil
of fennel plants can be used to alleviate
flatulent dyspepsia and colic's in children
(Singh et al., 2006).

The scarcity of water makes it difficult and expensive to expand the cultivated lands or even protect soils with natural cover. In Egypt, there is growing concern about the very limited water resource. Abu-Zeid (1999) indicated that, the country reached the so-called line in water resources with a per capita water share of almost $1000 \mathrm{~m}^{3} /$ person $I$ year. This is expected to fall to less than $\mathbf{5 0 0}$ $\mathrm{m}^{3}$ by 2030 , when the population reaches an estimated 100 million. Because of increasing population, demand for irrigation water will continue to increase. Irrigation uses more than $85 \%$ of the total renewable water in Egypt. So, efficient and effective water management is necessary. Most of plants are subjected to multitude of stresses through-out their life cycle. Salinity is one of the serious abiotic factors which are limiting the growth in different arid and semi-arid regions (Delgado et al., 1994). More than 800 million hectare of land in the world is affected by salinity and sodicity (Munns, 2005). There are different detrimental effects of salt stress in crop plants, responsible for severe decrease in the growth of plants. Ion imbalance, Osmotic stress (drought problem), particularly with $\mathrm{K}, \mathrm{Ca}$, and the direct toxic effects of ions on the metabolic process are the most important and widely studied physiological impairments caused by salinity (Zhu, 2001).

Salicylic acid (SA) has an important role in the regulation of plant growth and development, flowering, fruiting and seed germination (Klessig and Malamy, 1994). Photosynthetic rate, stomata conductance and transpiration could as well be influenced by the application of SA (Khan et al., 2003). Furthermore, using SA multiplies the production of reactive oxygen species like superoxide, hydrogen peroxide and hydroxyl radicals generation under stress, which leads to improvement of the antioxidant enzymes activities and increase plant tolerance to the abiotic stress (He et al., 2002).

Therefore, the objectives of our study are to evaluate the individual and combined effects of salicylic acid and different levels of irrigation water salinity on growth, yield and chemical compositions of fennel (Foeniculum vulgare, Mill.), variety of purple-bronze foliage grown on clayey-textured soil, in order to minimize the consumption of the fresh water reaching maintenance of soil fertility and crop production. 


\section{MATERIALS AND METHODS Soil sampling}

To achieve the purpose of this study, surface soil sample $(0-30 \mathrm{~cm})$ was collected from the Experimental Farm, Faculty of Agriculture, Menoufia University, Shebin El - Kom, Egypt $\left(30.52^{\circ} \mathrm{N}\right.$ and $\left.30.99^{\circ} \mathrm{E}\right)$. Soil samples were air - dried, ground, well mixed and sieved through a $2 \mathrm{~mm}$ sieve. A portion of the sieved soil sample was taken and analyzed for some soil physical and chemical analysis according to the methods described by Cottenie et al. (1982); Page et al. (1982) and Kim (1996), as shown in Table (1) .

\section{Irrigation water sources}

In this study, four salinity levels of irrigation water were used. Three artificial solutions which have EC of 3,5 and 7 $\left(\mathrm{dSm}^{-1}\right)$ for W2, W3 and W4 respectively, beside Nile water (W1), which is characterized by EC of $0.37 \mathrm{dSm}^{-1}$. These sources were variable in their salinity and also in their content of $\mathrm{Na}^{+}, \mathrm{Ca}^{2+}$ and $\mathrm{Mg}^{2+}$. The chemical composition of water sources was listed in Tables ( 2 and 3 ). The chemical composition of the used artificial water was assimilation of the ground water in the different regions of Menoufia Governorate, Egypt (Abou ElNour, 2013).

Table (1): Some physio-chemical properties and some macro and micro- nutrients of the experimental soil.

\begin{tabular}{|c|c|}
\hline Soil properties & Value \\
\hline $\begin{array}{l}\text { Particle size distribution (\%) } \\
\text { Coarse sand } \\
\text { Fine sand } \\
\text { Silt } \\
\text { Clay } \\
\text { Texture class } \\
\end{array}$ & $\begin{array}{c}6.35 \\
14.50 \\
25.00 \\
54.15 \\
\text { Clayey }\end{array}$ \\
\hline Water holding capacity (\%) & 62.8 \\
\hline Organic matter (\%) & 1.90 \\
\hline pH (1:2.5 soil : water suspension) & 7.55 \\
\hline$E C_{e}$ in soil paste extract $\left(\mathrm{dSm}^{-1}\right)$ & 1.51 \\
\hline CEC (cmol/kg) & 37.30 \\
\hline $\mathrm{CaCO}_{3}(\%)$ & 4.60 \\
\hline $\begin{array}{l}\text { Soluble cations (meq/l) } \\
\mathrm{Ca}^{++} \\
\mathrm{Mg}^{++} \\
\mathrm{Na}^{+} \\
\mathrm{K}^{+}\end{array}$ & $\begin{array}{l}4.48 \\
1.81 \\
6.55 \\
2.27\end{array}$ \\
\hline $\begin{array}{l}\text { Soluble anions (meq/l) } \\
\mathrm{CO}_{3}^{--} \\
\mathrm{HCO}_{3}^{-} \\
\mathrm{Cl}^{-} \\
\mathrm{SO}_{4}^{--}\end{array}$ & $\begin{array}{c}-- \\
1.44 \\
10.30 \\
3.37\end{array}$ \\
\hline $\begin{array}{l}\text { Available macronutrients }(\mathrm{mg} / \mathrm{kg} \text { soil) } \\
\mathrm{N} \\
\mathrm{P} \\
\mathrm{K}\end{array}$ & $\begin{array}{c}43.88 \\
7.80 \\
363.50\end{array}$ \\
\hline $\begin{array}{l}\text { Available micronutrients (mg/kg soil) } \\
\mathrm{Fe} \\
\mathrm{Mn} \\
\mathrm{Zn}\end{array}$ & $\begin{array}{l}6.82 \\
3.21 \\
1.08\end{array}$ \\
\hline
\end{tabular}


Table (2): Chemical composition of Nile water (W1).

\begin{tabular}{|c|c|c|c|c|c|c|c|c|c|c|}
\hline \multirow{2}{*}{$\mathrm{pH}$} & \multirow{2}{*}{$\begin{array}{c}\mathrm{EC} \\
\left(\mathrm{dSm}^{-1}\right)\end{array}$} & \multicolumn{3}{|c|}{ Soluble cations (meq/l) } & \multicolumn{4}{c|}{ Soluble anions (meq/I) } & \multirow{2}{*}{ SAR } \\
\cline { 3 - 10 } & $\mathrm{Na}^{+}$ & $\mathrm{K}^{+}$ & $\mathrm{Ca}^{2+}$ & $\mathrm{Mg}^{2+}$ & $\mathrm{Cl}^{-}$ & $\mathrm{CO}_{3}^{2-}$ & $\mathrm{HCO}_{3}^{-}$ & $\mathrm{SO}_{4}^{2-}$ & \\
\hline 7.80 & 0.37 & 1.15 & 0.20 & 1.14 & 1.21 & 0.94 & 0.00 & 1.81 & 0.95 & \multirow{2}{*}{1.06} \\
\hline
\end{tabular}

Table (3): Chemical compositions of the irrigation artificial water.

\begin{tabular}{|c|c|c|c|c|c|c|c|c|}
\hline \multirow{2}{*}{$\begin{array}{c}\text { Water } \\
\text { code }\end{array}$} & \multicolumn{2}{|c|}{$\mathrm{NaCl}$} & \multicolumn{2}{c|}{$\mathrm{CaCl}_{2}$} & \multicolumn{2}{c|}{$\mathrm{MgCl}_{2}$} & \multirow{2}{*}{$\begin{array}{c}\mathrm{EC} \\
\left(\mathrm{dSm}^{-1}\right)\end{array}$} & \multirow{2}{*}{ SAR } \\
\cline { 2 - 8 } & $(\mathrm{mg} / \mathrm{l})$ & $(\mathrm{meq} / \mathrm{l})$ & $(\mathrm{mg} / \mathrm{l})$ & $(\mathrm{meq} / \mathrm{l})$ & $(\mathrm{mg} / \mathrm{l})$ & $(\mathrm{meq} / \mathrm{l})$ & \\
\hline W2 & 1233.77 & 21.09 & 246.98 & 4.45 & 209.48 & 4.41 & 3 & 10.00 \\
\hline W3 & 1807.65 & 30.90 & 530.03 & 9.55 & 449.83 & 9.47 & 5 & 10.00 \\
\hline W4 & 2297.30 & 39.27 & 861.36 & 15.52 & 722.48 & 15.21 & 7 & 10.00 \\
\hline
\end{tabular}

\section{Pot experiment}

During two successive growth winter seasons, viz. namely 2013/2014 and 2014/2015, a pots experiment was carried out at the Experimental Farm, Faculty of Agriculture, Menoufia University, Shebin El-Kom, Egypt to study the response of fennel plant to foliar application of salicylic acid (SA) at different rates $(0,50$, 100,150 and $200 \mathrm{mg} / \mathrm{l}$ ) alone and in combinations with different salinity levels of irrigation water (W1, W2, W3 and W4) to produce 20 treatments. First foliar application of SA was done after three weeks of planting and was repeated every month in the early morning till the end of experiment. The experimental units were 600 plastic pots, including 5 rates of salicylic acid $\times 4$ salinity levels of irrigation water $\times 3$ replicates $\times 10$ pots for each replicate. Plastic pots of $25 \mathrm{~cm}$ depth and $30 \mathrm{~cm}$ diameter were used in this study. A disc of filter paper was placed at the bottom of each pot to prevent soil loss through the drainage holes. Each pot was filled with $4 \mathbf{~ k g}$ of prepared fine clay soil. Before planting, all pots were fertilized by ordinary superphosphate $\left(15.5 \% \mathrm{P}_{2} \mathrm{O}_{5}\right)$ at rate of $200 \mathrm{~kg} \mathrm{P} \mathrm{P}_{2} \mathrm{O}_{5} / \mathrm{fed}$. "feddan $=4200 \mathrm{~m}^{2}$ " $(0.8$ g (pot). Also, every pot received $2 \%$ maturely compost. The experiment was carried out in completely randomized block design (CRBD) with three replicates. In two growth seasons, seeds of fennel (Foeniculum vulgare, Mill.), variety of purple-bronze foliage were obtained from Medicinal and Aromatic Plants Res. Dept., Hort. Res. Inst., Agric. Res. Center, Giza, Egypt.

Each pot was sown at 1st October, 2013 and 2014 by five seeds of fennel (first and second seasons). After $\mathbf{1 5}$ days of sowing, plants were thinned to one plant. After thinning, all pots were fertilized by potassium sulphate (48\% $\mathrm{K} 2 \mathrm{O}$ ) as a potassium fertilizer at rate of $200 \mathrm{~kg} \mathrm{K2O} / \mathrm{fed}(0.8 \mathrm{~g} / \mathrm{pot})$ and nitrogen was added as ammonium nitrate (33 $\% \mathrm{~N})$ at rate of $240 \mathrm{~kg} \mathrm{~N} / \mathrm{fed}(0.96 \mathrm{~g} / \mathrm{pot})$. Then as basic fertilization, and added in four equal doses after $30,60,90$ and 120 days of planting. During the experimental period (seven months), all pots were irrigated by the tested types of irrigation water at $60 \%$ of soil water holding capacity (WHC).

\section{Preparation and analyses of plant samples}

At the end of the two seasons (after seven months from planting), the plants of each replicate was harvested separately to examine parameters as follows: 


\section{1- Morphological parameters}

Fruits were harvested before it was fully ripe, in other words when it was sufficiently hard and greenish gray in color. Umbels were air-dried and the following parameters were recorded such as plant height $(\mathrm{cm})$, fresh weight of whole plant (g/plant), number of main branches/plant, number of umbels/plant, fresh and dry weights of umbels (g/plant), weight of 100 fruits (g/plant) and fruit yield (g/plant).

\section{2- Chemical constituents}

Essential oil percentages were determined in the air dried fruits in both seasons as described by British Pharmacopea (1963). Essential oil yield per plant was calculated by multiplying fruit yield per plant by essential oil percentage. The essential oil obtained from the fruits in the second season was analyzed using GLC Model HP-5890 with flame ionization detector that was fitted with capillary column, coated with carbowax 20M. The operating conditions were injector temperature $190{ }^{\circ} \mathrm{C}$, detector temperature $220{ }^{\circ} \mathrm{C}$, Linear temperature programmed at $4{ }^{\circ} \mathrm{C} \mathrm{min}$, to $150{ }^{\circ} \mathrm{C}$ min, nitrogen (carrier gas) flow $1.5 \mathrm{ml} / \mathrm{min}$, hydrogen $30 \mathrm{ml} / \mathrm{min}$, air $300 \mathrm{ml} / \mathrm{min}$. The peaks were recorded and areas were determined by using HPintegrator, 0:1 component was identified by comparing the relation times of the authentic compounds.

Total carbohydrate (\%) in the dried herb of fennel plants was determined using the colorimetric method described by Dubois et al. (1956).

Photosynthetic pigments (chlorophyll a, $b$ and carotenoids) were determined in fresh leaves as the methods described by Witham et al. (1971).

Samples of the harvested plants were washed several times with a tap-water and then two times with distilled water, air-dried, oven-dried at $70^{\circ} \mathrm{C}$ for 48 hour, ground separately to a fine powder in a stainless grinder and stored in plastic bags until analysis. A half $g$ portion of each dried plant sample was digested by $5 \mathrm{ml}$ of concentrated mixture of $\mathrm{H}_{2} \mathrm{SO}_{4}+$ $\mathrm{HClO}_{4}$ at (5:0.5 ratio) according to Chapman and Pratt (1982). The contents (\%) of $\mathrm{N}, \mathrm{P}$ and $\mathrm{K}$ were determined as described by Cottenie et al. (1982).

\section{Statistical analysis}

The obtained data of growth parameters were exposed to proper statistical analysis of variance (ANOVA) by using Minitab computer program and least significant difference (L.S.D.) were calculated at level of $5 \%$ (Barbara and Brain, 1994).

\section{RESULTS AND DISCUSSION:}

Effect of salicylic acid (SA) application and different salinity levels of irrigation water and their interactions on:

\section{1-Morphological characteristics:}

A glance on Table (4), the summary of the statistical analysis for the morphological characteristics show that, treated fennel plants with irrigation water salinity (W2) slightly increased plant height, number of main branches/plant and fresh weight of whole plant, while the higher levels of salinity W3 and W4 were associated by a significant decrease in most morphological characteristics compared to untreated plants. The inhibitory decrease effects of salinity on vegetative growth of fennel plants might be due to reduced water absorption, reduced metabolic activities due to $\mathrm{Na}^{+}$ and $\mathrm{Cl}^{-}$toxicity and nutrient deficiency caused by ionic interference (De Lacerda et al., 2003). Similar reduction effect on plant growth due to high salinity levels is in harmony with the results obtained by Eid et al., (2011) on marigold plants and Khalid and Shedeed (2014) on Nigella sativa plants. 
Table (4): Effect of different salicylic acid rates, salinity levels of irrigation water and their interactions on morphological characteristics of fennel plants during two growing seasons.

\begin{tabular}{|c|c|c|c|c|c|c|c|c|c|c|}
\hline \multirow{2}{*}{$\begin{array}{l}\text { Water salinity } \\
\text { levels } \\
\text { Salicylic acid } \\
\text { (mg/l) }\end{array}$} & \multicolumn{5}{|c|}{$2013 / 2014$} & \multicolumn{5}{|c|}{$2014 / 2015$} \\
\hline & W1 & W2 & W3 & W4 & Mean & W1 & W2 & W3 & W4 & Mean \\
\hline \multicolumn{11}{|c|}{ Plant height (cm) } \\
\hline 0 & 97.36 & 86.94 & 84.22 & 84.41 & 88.23 & 110.66 & 103.42 & 92.71 & 85.93 & 98.18 \\
\hline 50 & 106.73 & 112.11 & 100.71 & 95.91 & 103.86 & 113.05 & 119.50 & 100.91 & 92.80 & 106.56 \\
\hline 100 & 117.28 & 121.86 & 110.73 & 108.60 & 114.61 & 124.39 & 131.00 & 128.11 & 116.23 & 124.93 \\
\hline 150 & 123.52 & 128.09 & 117.18 & 112.40 & 120.29 & 125.34 & 138.68 & 135.75 & 120.69 & 130.11 \\
\hline 200 & 115.25 & 115.47 & 107.62 & 99.53 & 109.46 & 117.01 & 112.80 & 99.15 & 90.63 & 104.89 \\
\hline Mean & 112.02 & 112.89 & 104.09 & 100.17 & & 118.09 & 121.08 & 111.32 & 101.25 & \\
\hline L.S.D. at $5 \%$ & \multicolumn{5}{|c|}{ Salinity $=8.04 \quad S A=8.92 \quad$ Salinity $\times \mathrm{SA}=17.80$} & \multicolumn{5}{|c|}{ Salinity $=11.30 \mathrm{SA}=12.50$ Salinity $\times \mathrm{SA}=\mathbf{2 4 . 9 8}$} \\
\hline \multicolumn{11}{|c|}{ Number of main branches / plant } \\
\hline 0 & 9.65 & 8.72 & 8.26 & 7.71 & 8.58 & 9.17 & 9.03 & 8.50 & 8.23 & 8.73 \\
\hline 50 & 9.83 & 10.62 & 9.65 & 8.53 & 9.65 & 10.15 & 10.17 & 9.61 & 9.27 & 9.80 \\
\hline 100 & 10.33 & 10.90 & 9.71 & 9.48 & 10.10 & 10.53 & 11.22 & 10.85 & 9.78 & 10.59 \\
\hline 150 & 10.60 & 11.18 & 10.25 & 9.93 & 10.49 & 11.42 & 11.63 & 10.50 & 10.13 & 10.92 \\
\hline 200 & 9.82 & 9.71 & 8.59 & 8.21 & 9.08 & 11.07 & 10.93 & 9.88 & 8.76 & 10.16 \\
\hline Mean & 10.04 & 10.22 & 9.29 & 8.77 & & 10.46 & 10.59 & 9.86 & 9.23 & \\
\hline L.S.D. at $5 \%$ & \multicolumn{5}{|c|}{ Salinity $=1.05 \quad S A=1.17 \quad$ Salinity $\times \mathrm{SA}=2.33$} & \multicolumn{5}{|c|}{ Salinity $=N S \quad S A=1.71 \quad$ Salinity $\times S A=N S$} \\
\hline \multicolumn{11}{|c|}{ Fresh weight of whole plant (g/ plant) } \\
\hline 0 & 167.18 & 146.26 & 125.43 & 119.56 & 139.60 & 181.73 & 162.25 & 143.49 & 127.55 & 153.75 \\
\hline 50 & 189.72 & 209.84 & 171.95 & 157.08 & 182.14 & 205.18 & 234.29 & 182.21 & 165.33 & 196.75 \\
\hline 100 & 225.20 & 258.16 & 210.29 & 181.47 & 218.78 & 235.66 & 264.45 & 220.79 & 204.93 & 231.45 \\
\hline 150 & 261.52 & 291.68 & 243.20 & 208.75 & 251.28 & 272.80 & 301.15 & 257.60 & 216.99 & 262.13 \\
\hline 200 & 234.60 & 246.55 & 197.24 & 175.68 & 213.51 & 220.40 & 229.71 & 192.58 & 184.39 & 206.77 \\
\hline Mean & 215.64 & 230.49 & 189.62 & 168.50 & & 223.15 & 238.37 & 199.33 & 179.83 & \\
\hline L.S.D. at $5 \%$ & \multicolumn{5}{|c|}{ Salinity $=18.27 \quad S A=20.28$ Salinity $\times S A=40.56$} & \multicolumn{5}{|c|}{ Salin. $=20.11 \quad S A=22.32$ Salinity $\times S A=44.64$} \\
\hline
\end{tabular}

Also the results in Table (4) show that, all the studied vegetative growth characters were significantly increased as a result of foliar application of SA compared to the control in both seasons.
The most effective enhancement in this regard was obtained by using $S A$ at the rate of $150 \mathrm{mg} / \mathrm{l}$. The promotive effect of SA on morphological growth characters could be attributed to its bioregulator 
effects on physiological and biochemical processes in plants, such as ion uptake, cell elongation, cell division, cell differentiation, sink and source regulation, enzymatic activities, protein synthesis and photosynthetic activity as well as the increase in the antioxidant capacity of plant.

Using SA as anti-stress substance may enhance the plant tolerance to environmental stresses. These results are in quite agreement with the findings of Al-Qubaie (2013) on Jasminum sambac and Ali et al. (2016) on Ammi visnaga.

By referring to the obtained data in Table (4), it was clear that, plant trails growth was markedly influenced by all applied salinity levels combined with different SA concentrations. The most prominent decline in plant growth was associated with the highest salinity level W4. On the other hand, the greatest values of growth parameters were recorded in the plants sprayed with SA at $150 \mathrm{mg} / \mathrm{l}$ under low salinity levels. In this concern, SA might show anti-stress effects under salinity conditions and it may enhance the uptake of nutrients and reduce the uptake of some toxic elements. These results are in accordance with Hassan and Ali (2014) on jojoba plants.

\section{2-Yield parameters:}

Recorded results in Table (5) show that, high salinity levels caused a drastic decline in the measured yield parameters, i.e. number of umbels per plant, fresh and dry weights of umbels (g/plant), weight of 100 fruits (g/plant) and fruit yield (g/plant). Such inhibition was gradually minimized with increasing salinity levels. On the contrary, all these criteria were increased under the lowest level of salinity W2. Reduction in fennel yield at high salinity levels might be associated with several physiological responses including modification of ion balance, water status, stomata behavior, photosynthetic efficiency, carbon allocation and utilization which in turn affect the yield (Munns, 2002 and 2005). The suppressive effect of salinity on yield was also considered as a consequent event to the marked inhibition in photosynthesis (Chartzoulakis and Klapaki, 2000). These results support the previous results obtained by Ali et al. (2014) on rose and Yu et al. (2015) on mint plants.

The obtained results of the current study obviously reveal that, spraying SA at 50 to $200 \mathrm{mg} / \mathrm{l}$ was responsible for enhancing yield parameters (Table, 5). A sharp increase of the measured yield components were observed especially with the foliar application of SA at rate of $150 \mathrm{mg} / \mathrm{l}$, except seed index (weight of 100 fruits g/plant), which reached its maxima at rate of $100 \mathrm{mg} \mathrm{SA} / \mathrm{l}$ compared to untreated plants and other treatments during both seasons.

The beneficial effect of SA on yield may be attributed to the enhancement effect of SA on vegetative growth and many enzymes activities. These results are comparable to those reported by Ali et al. (2016) on Ammi visnaga and Hassan et al. (2017) on rosemary.

Concerning the interactions between salinity and SA at different rates, the combined treatment among salinity at the lowest level W2 and SA at (150 mg/l) induced the highest mean values of these parameters than others salinity levels and SA concentrations except seed index which reached its maximum value by using salt stress at W2 combined with SA at (100 $\mathrm{mg} / \mathrm{l})$. These results are similar to those obtained by Fayez and Bazaid (2014) on barley plants. 
Table (5): Effect of different salicylic acid rates, salinity levels of irrigation water and their interactions on some yield parameters of fennel plants during two growing seasons .

\begin{tabular}{|c|c|c|c|c|c|c|c|c|c|c|}
\hline \multirow{2}{*}{$\begin{array}{c}\text { Water salinity } \\
\text { levels } \\
\text { Salicylic acid } \\
\text { (mq/l) }\end{array}$} & \multicolumn{5}{|c|}{$2013 / 2014$} & \multicolumn{5}{|c|}{ 2014/2015 } \\
\hline & W1 & W2 & W3 & W4 & Mean & W1 & W2 & W3 & W4 & Mean \\
\hline \multicolumn{11}{|c|}{ Number of umbels/plant } \\
\hline 0 & 17.06 & 15.87 & 14.18 & 12.74 & 14.96 & 19.48 & 16.37 & 14.29 & 14.85 & 16.24 \\
\hline 50 & 19.32 & 22.14 & 18.65 & 17.51 & 19.40 & 21.18 & 23.26 & 20.33 & 17.60 & 20.59 \\
\hline 100 & 22.29 & 24.12 & 20.45 & 19.67 & 21.63 & 25.55 & 29.94 & 24.87 & 22.15 & 25.62 \\
\hline 150 & 25.81 & 26.29 & 22.40 & 20.65 & 23.78 & 26.62 & 29.37 & 26.52 & 23.12 & 26.40 \\
\hline 200 & 24.20 & 24.39 & 22.67 & 19.05 & 22.57 & 25.87 & 26.04 & 22.75 & 22.23 & 24.22 \\
\hline Mean & 21.73 & 22.56 & 19.67 & 17.92 & & 23.74 & 24.99 & 21.75 & 19.99 & \\
\hline L.S.D. at 5\% & \multicolumn{5}{|c|}{ Salinity $=2.23 \quad S A=2.48$ Salinity $\times$ SA=4.95 } & \multicolumn{5}{|c|}{ Salinity $=2.09 \mathrm{SA}=2.32 \quad$ Salinity $\times \mathrm{SA}=4.64$} \\
\hline \multicolumn{11}{|c|}{ Fresh weight of umbels/plant $(\mathrm{g})$} \\
\hline 0 & 38.56 & 34.92 & 29.52 & 28.12 & 32.76 & 41.47 & 39.18 & 30.38 & 29.05 & 35.02 \\
\hline 50 & 44.35 & 49.77 & 36.03 & 32.65 & 40.70 & 49.27 & 52.89 & 41.58 & 40.76 & 46.12 \\
\hline 100 & 49.36 & 55.20 & 45.73 & 37.01 & 46.82 & 53.14 & 58.62 & 42.95 & 42.27 & 49.24 \\
\hline 150 & 58.27 & 62.92 & 48.79 & 43.32 & 53.32 & 62.54 & 68.32 & 53.87 & 48.33 & 58.26 \\
\hline 200 & 52.17 & 57.41 & 44.56 & 38.04 & 48.04 & 50.41 & 51.49 & 47.20 & 43.99 & 48.27 \\
\hline Mean & 48.53 & 52.04 & 40.92 & 35.82 & & 51.36 & 54.10 & 43.19 & 40.88 & \\
\hline L.S.D. at $5 \%$ & \multicolumn{5}{|c|}{ Salinity $=7.68$ SA $=8.52$ Salinity $\times S A=17.05$} & \multicolumn{5}{|c|}{ Salinity $=5.91 \mathrm{SA}=6.56$ Salinity $\times \mathrm{SA}=13.12$} \\
\hline \multicolumn{11}{|c|}{ Dry weight of umbels/plant (g) } \\
\hline 0 & 25.37 & 22.68 & 19.05 & 18.75 & 21.46 & 26.25 & 25.61 & 20.39 & 19.52 & 22.94 \\
\hline 50 & 27.72 & 30.48 & 23.04 & 20.80 & 25.51 & 31.50 & 33.91 & 27.18 & 26.88 & 29.86 \\
\hline 100 & 31.05 & 34.29 & 29.44 & 24.51 & 29.82 & 34.29 & 36.48 & 28.26 & 28.16 & 31.79 \\
\hline 150 & 37.12 & 39.68 & 32.50 & 29.21 & 34.62 & 39.84 & 43.52 & 33.67 & 31.59 & 37.15 \\
\hline 200 & 33.02 & 36.12 & 28.75 & 25.20 & 30.77 & 32.55 & 33.62 & 29.84 & 28.91 & 31.23 \\
\hline Mean & 30.85 & 32.65 & 26.55 & 23.69 & & 32.88 & 34.62 & 27.86 & 27.01 & \\
\hline L.S.D. at $5 \%$ & \multicolumn{5}{|c|}{ Salinity=4.82 $S A=5.35$ Salinity $\times S A=10.17$} & \multicolumn{5}{|c|}{ Salinity $=5.69 \mathrm{SA}=6.32$ Salinity $\times \mathrm{SA}=12.63$} \\
\hline \multicolumn{11}{|c|}{ Weight of 100 fruits (g/plant) } \\
\hline 0 & 0.95 & 0.91 & 0.88 & 0.83 & 0.89 & 0.86 & 0.83 & 0.81 & 0.80 & 0.82 \\
\hline 50 & 0.98 & 1.03 & 0.92 & 0.86 & 0.94 & 0.91 & 0.91 & 0.89 & 0.84 & 0.88 \\
\hline 100 & 1.18 & 1.22 & 1.13 & 0.96 & 1.12 & 1.23 & 1.27 & 1.20 & 1.16 & 1.21 \\
\hline 150 & 1.11 & 1.16 & 1.09 & 0.97 & 1.08 & 1.15 & 1.15 & 1.00 & 0.92 & 1.05 \\
\hline 200 & 1.07 & 1.01 & 0.93 & 0.89 & 0.97 & 1.06 & 0.97 & 0.92 & 0.89 & 0.96 \\
\hline Mean & 1.05 & 1.06 & 0.99 & 0.90 & & 1.04 & 1.02 & 0.96 & 0.92 & \\
\hline L.S.D. at $5 \%$ & \multicolumn{5}{|c|}{ Salinity $=\mathbf{N S} \quad$ SA=NS $\quad$ Salinity $\times$ SA $=\mathbf{N S}$} & \multicolumn{5}{|c|}{ Salinity $=$ NS $S A=0.33 \quad S$} \\
\hline & \multicolumn{10}{|c|}{ Fruit yield (g/plant) } \\
\hline 0 & 20.62 & 18.70 & 15.13 & 15.81 & 17.56 & 21.28 & 20.43 & 16.63 & 15.17 & 18.37 \\
\hline 50 & 22.40 & 24.57 & 18.19 & 16.66 & 20.45 & 25.85 & 27.78 & 22.99 & 21.60 & 24.55 \\
\hline 100 & 25.08 & 27.94 & 23.68 & 19.52 & 24.05 & 27.39 & 28.58 & 23.81 & 22.88 & 25.66 \\
\hline 150 & 29.33 & 31.39 & 25.81 & 23.77 & 27.57 & 31.09 & 34.18 & 27.54 & 25.75 & 29.64 \\
\hline 200 & 27.21 & 29.40 & 24.15 & 21.50 & 25.56 & 27.26 & 29.50 & 24.33 & 24.90 & 26.49 \\
\hline Mean & 24.92 & 26.40 & 21.39 & 19.45 & & 26.57 & 28.09 & 23.06 & 22.06 & \\
\hline L.S.D. at $5 \%$ & \multicolumn{5}{|c|}{ Salinity= $6.47 \quad S A=7.18$ Salinity $\times$ SA $=14.36$} & \multicolumn{5}{|c|}{ Salinity $=4.97 \quad S A=5.52$} \\
\hline
\end{tabular}




\section{3-Volatile oil content (\%) and oil yield:}

Data in Table (6) show that, increasing salinity levels in the two seasons caused significant and progressive increments in volatile oil content (\%) of fennel fruit, where the highest value was obtained in plants was irrigated with W3 and the lowest mean occurred under plants was irrigated with W1 level. While volatile oil yield (cc/plant) was slightly increased by increasing salinity levels from W1 to W2 and by using higher salinity levels (W3 and W4) the value of oil yield (cc/plant) has gradually decreased. It has been suggested that, salinity can increase the synthesis of some secondary metabolites such as volatile oil and encourage the formation of new compounds (Simon et al., 1992). Similar findings were reported by Rahimi et al. (2012) on fennel plants.

Also, data in Table (6) show that, there were significant positive effects of all SA treatments on volatile oil content (\%) and oil yield (cc/plant) compared to untreated plants, where the highest significant content of volatile oil and oil yield were happened as a result of SA foliar spraying at rates of 100 and 150 $\mathrm{mg} / \mathrm{l}$, respectively. These results are in agreements with those investigated by Gharib (2006) on basil and marjoram plants.

Table (6): Effect of different salicylic acid rates, salinity levels of irrigation water and their interactions on volatile oil percentage and oil yield/plant of fennel plants during two seasons.

\begin{tabular}{|c|c|c|c|c|c|c|c|c|c|c|}
\hline \multirow{2}{*}{$\begin{array}{l}\text { Water salinity } \\
\text { Levels } \\
\text { Salicylic acid } \\
\text { (mg/l) }\end{array}$} & \multicolumn{5}{|c|}{$2013 / 2014$} & \multicolumn{5}{|c|}{$2014 / 2015$} \\
\hline & W1 & W2 & w3 & W4 & Mean & W1 & W2 & w3 & W4 & Mean \\
\hline \multicolumn{11}{|c|}{ Oil (\%) } \\
\hline 0 & 1.43 & 1.56 & 1.66 & 1.56 & 1.55 & 1.55 & 1.56 & 1.68 & 1.68 & 1.61 \\
\hline 50 & 1.55 & 1.68 & 1.75 & 1.88 & 1.71 & 1.68 & 1.75 & 1.80 & 1.88 & 1.77 \\
\hline 100 & 1.80 & 1.93 & 2.06 & 1.98 & 1.94 & 1.93 & 1.98 & 1.98 & 1.88 & 1.94 \\
\hline 150 & 1.66 & 1.66 & 1.93 & 1.76 & 1.75 & 1.56 & 1.76 & 1.88 & 1.80 & 1.75 \\
\hline 200 & 1.63 & 1.88 & 1.76 & 1.76 & 1.75 & 1.66 & 1.76 & 1.63 & 1.56 & 1.65 \\
\hline Mean & 1.61 & 1.74 & 1.83 & 1.78 & & 1.67 & 1.76 & 1.79 & 1.76 & \\
\hline L.S.D. at $5 \%$ & Salinity $=0.12$ & $\mathrm{SA}=$ & 0.13 & Salinity $x$ & $\mathrm{SA}=\mathrm{NS}$ & Salinity & $=$ NS S & $A=0.22$ & Salinity & $S A=N S$ \\
\hline \multicolumn{11}{|c|}{ Oil yield ( cc/plant ) } \\
\hline 0 & 0.29 & 0.29 & 0.25 & 0.24 & 0.26 & 0.32 & 0.31 & 0.27 & 0.25 & 0.28 \\
\hline 50 & 0.34 & 0.41 & 0.31 & 0.31 & 0.34 & 0.43 & 0.48 & 0.41 & 0.40 & 0.43 \\
\hline 100 & 0.45 & 0.53 & 0.48 & 0.38 & 0.46 & 0.52 & 0.56 & 0.47 & 0.43 & 0.49 \\
\hline 150 & 0.48 & 0.52 & 0.49 & 0.41 & 0.47 & 0.48 & 0.60 & 0.51 & 0.46 & 0.51 \\
\hline 200 & 0.44 & 0.55 & 0.42 & 0.37 & 0.44 & 0.45 & 0.51 & 0.39 & 0.38 & 0.43 \\
\hline Mean & \begin{tabular}{|l|}
0.40 \\
\end{tabular} & 0.46 & 0.39 & 0.34 & & 0.44 & 0.49 & 0.41 & 0.38 & \\
\hline L.S.D. at $5 \%$ & \multicolumn{5}{|c|}{ Salinity $=0.03$ SA $=0.04 \quad$ Salinity $\times$ SA $=0.07$} & \multicolumn{5}{|c|}{ Salinity $=0.05$ SA $=0.06$ Salinity $\times S A=0.11$} \\
\hline
\end{tabular}


Dual appliance of SA concentrations and salinity levels of irrigation water and its interactions resulted in increments in the content (\%) of volatile oil and oil yield (cc/plant) compared to that obtained from untreated plants. Combined treatments of $\mathrm{SA}$ at $100 \mathrm{mg} / \mathrm{l}+\mathrm{W} 3$ level and SA at 150 mgll + W2 level gave the highest content (\%) of volatile oil and oil yield, respectively. These results were found in the first and second seasons. Similar improvements were obtained by Hassan et al. (2017) on rosemary.

\section{4-Photosynthetic pigments:}

With regard to the effect of irrigation by different levels of salinity on photosynthetic pigments, data in Table (7) illustrate that, those plant irrigated by W2 and W3 levels increased photosynthetic pigments (chlorophyll a, b and carotenoids $\mathrm{mg} / \mathrm{g}$ of fresh weight), while the lowest favorable effect was reported by the irrigation of $\mathrm{W} 4$ level. The greatest increment in chlorophyll $a$ and $b$ were found in plants irrigated by W2 level, while plants irrigated by W3 level have produced the highest content of carotenoids in the fresh leaves.

Table (7): Effect of different salicylic acid rates, salinity levels of irrigation water and their interactions on photosynthetic pigments of fennel plants during two growing seasons.

\begin{tabular}{|c|c|c|c|c|c|c|c|c|c|c|}
\hline \multirow{2}{*}{$\begin{array}{l}\text { Water salinity } \\
\text { levels } \\
\text { Salicylic acid } \\
\text { (mg/l) }\end{array}$} & \multicolumn{5}{|c|}{$2013 / 2014$} & \multicolumn{5}{|c|}{ 2014/2015 } \\
\hline & W1 & W2 & W3 & W4 & Mean & W1 & W2 & W3 & W4 & Mean \\
\hline & \multicolumn{10}{|c|}{ Chlorophyll A (mg/g) } \\
\hline 0 & 3.19 & 3.25 & 3.17 & 3.10 & 3.17 & 3.26 & 3.35 & 3.30 & 3.19 & 3.27 \\
\hline 50 & 3.30 & 3.41 & 3.29 & 3.22 & 3.30 & 3.42 & 3.56 & 3.38 & 3.31 & 3.41 \\
\hline 100 & 4.58 & 4.73 & 4.52 & 4.46 & 4.57 & 4.36 & 4.59 & 4.25 & 4.17 & 4.34 \\
\hline 150 & 4.40 & 4.47 & 4.33 & 4.26 & 4.36 & 4.08 & 4.21 & 4.29 & 4.11 & 4.17 \\
\hline 200 & 3.67 & 3.74 & 3.86 & 3.59 & 3.71 & 3.53 & 3.64 & 3.50 & 3.49 & 3.54 \\
\hline Mean & 3.82 & 3.92 & 3.83 & 3.72 & & 3.73 & 3.87 & 3.74 & 3.65 & \\
\hline \multirow[t]{2}{*}{ L.S.D. at $5 \%$} & \multicolumn{5}{|c|}{ Salinity = NS SA=1.11 Salinity $\times$ SA $=$ NS } & \multicolumn{3}{|c|}{ Salinity $=$ NS $S A=1.22$} & \multicolumn{2}{|c|}{ Salinity $\times$ SA $=$ NS } \\
\hline & \multicolumn{10}{|c|}{ Chlorophyll B (mg/g) } \\
\hline 0 & 1.23 & 1.31 & 1.19 & 1.14 & 1.21 & 1.29 & 1.36 & 1.24 & 1.20 & 1.27 \\
\hline 50 & 1.45 & 1.56 & 1.39 & 1.28 & 1.42 & 1.53 & 1.60 & 1.47 & 1.38 & 1.49 \\
\hline 100 & 2.10 & 2.57 & 2.42 & 2.39 & 2.37 & 2.02 & 2.35 & 2.27 & 2.13 & 2.19 \\
\hline 150 & 2.05 & 2.20 & 2.23 & 2.16 & 2.16 & 1.98 & 2.18 & 2.11 & 2.04 & 2.07 \\
\hline 200 & 1.58 & 1.67 & 1.50 & 1.48 & 1.55 & 1.56 & 1.64 & 1.58 & 1.47 & 1.56 \\
\hline Mean & 1.68 & 1.86 & 1.74 & 1.69 & & 1.67 & 1.82 & 1.73 & 1.64 & \\
\hline \multirow[t]{2}{*}{ L.S.D. at $5 \%$} & \multicolumn{5}{|c|}{ Salinity $=0.09 \quad S A=0.10 \quad$ Salinity $\times \mathrm{SA}=0.20$} & \multicolumn{3}{|c|}{ Salinity $=0.11 \mathrm{SA}=0.12$} & \multicolumn{2}{|c|}{ Salinity $\times$ SA $=0.24$} \\
\hline & \multicolumn{10}{|c|}{ Carotenoids (mg/g) } \\
\hline 0 & 2.19 & 2.33 & 2.30 & 2.21 & 2.25 & 2.35 & 2.39 & 2.40 & 2.31 & 2.36 \\
\hline 50 & 2.42 & 2.56 & 2.64 & 2.39 & 2.50 & 2.55 & 2.59 & 2.71 & 2.43 & 2.57 \\
\hline 100 & 3.12 & 3.40 & 3.54 & 3.32 & 3.34 & 3.21 & 3.38 & 3.46 & 3.30 & 3.33 \\
\hline 150 & 3.08 & 3.20 & 3.16 & 3.09 & 3.13 & 3.18 & 3.20 & 3.24 & 3.15 & 3.19 \\
\hline 200 & 2.53 & 2.66 & 2.78 & 2.44 & 2.60 & 2.71 & 2.84 & 2.69 & 2.65 & 2.72 \\
\hline Mean & 2.66 & 2.83 & 2.88 & 2.69 & & 2.80 & 2.88 & 2.90 & 2.76 & \\
\hline L.S.D. at $5 \%$ & \multicolumn{3}{|c|}{ Salinity $=$ NS } & \multicolumn{2}{|c|}{ Salinity $\times$ SA $=$ NS } & \multicolumn{3}{|c|}{ Salinity $=$ NS } & \multicolumn{2}{|c|}{ Salinity $\times$ SA $=$ NS } \\
\hline
\end{tabular}


The negative effects of the highest salinity levels on photosynthetic pigments could be due to the inhibition of chlorophyll biosynthesis or the increase of its degradation by chlorophyllase, which is more active under salinity stress (Khan et al., 2006; Ziaf et al., 2009 and Akça and Samsunlu, 2012). Furthermore, an oxidative stress could happen due to salinity stress leading to deterioration in chloroplast structure, and consequently decrease in chlorophyll content. This finding in the current study was supported by AbdulQados (2015) on Capsicum annuum plants.

External addition of SA significantly increased the values of photosynthetic pigments (chlorophyll a, b and carotenoids $\mathrm{mg} / \mathrm{g}$ of fresh weight) as shown in Table (7). Spraying SA at rate of (100 mg/l) gave the highest values of these determinations relative to untreated plants during two successive winter seasons. It seems that, SA can facilitate respiration and photosynthesis processes via modified functioning of mitochondria and chloroplasts, so that the negative effects of abiotic stresses on plants can be alleviated by the use of SA (Singh and Usha, 2003). Such increments were obtained by Kabiri et al. (2014) on Nigella sativa plants.

In view of our results, plants treated with both SA and salt stress showed a slight increase in the determination of photosynthetic pigments during two seasons (Table, 7). These plants have reached their maximum contents of (chlorophyll $a$ and $b$ ) in the plants treated by SA at rate of $100 \mathrm{mg} / \mathrm{l}+$ W2 level while, the highest content of carotenoids was observed in the plants treated by SA at rate of $100 \mathrm{mg} / \mathrm{l}+\mathrm{W} 3$ level in both seasons. These results are in agreement with those obtained by Hassan et al. (2017) on rosemary plants.

\section{5-Nutrients and total carbohydrate content (\%):}

Data of nutrients content (\%) of fennel plants (Table, 8), reveal that, salinity stress had adversely reduced the nutrients content of ( $N, P$ and $K$ ), where the magnitude of reduction was increased with increasing salinity levels, as compared to plants irrigated with nonsaline water (control). On the other side, increasing salinity levels of irrigation water led to an increase in total carbohydrate (\%) in most cases which reached its maximum value by the application of W3 level during two growing seasons.

Salinity treatment at these levels enhanced the accumulation of leaf $\mathrm{Na}^{+}$ and $\mathrm{Cl}^{-}$ions, thereby reducing plant growth rate and hence minimizing the ion uptake by the roots and ion accumulation in the shoots are important mechanisms of salt tolerance (Caia et al.,2014). Several researchers found that, increasing salinity level decreased nutrients content e.g. Hashish et al., (2015) on gladiolus plants and Hassan and Ali (2014) on jojoba plants.

The response of $\mathrm{N}, \mathrm{P}, \mathrm{K}$ and total carbohydrate contents (\%) in the dried herb of fennel plants to different concentrations of SA are illustrated in Table (8). All tested SA concentrations increased N, P, K and total carbohydrates contents. Foliar applications of SA at rates of 100 and $200 \mathrm{mg} / \mathrm{L}$ induced the highest $N$ and $P$ values, respectively, while its adequacy at rate of $150 \mathrm{mg} / \mathrm{l}$ caused the highest percentages of $K$ and total carbohydrate in the two winter seasons. This means that, SA might show anti-stress effects under salinity levels and may enhance the uptake of nutrients and reduce the uptake of some toxic elements (Karlidag et al., 2009). In this respect, previous studies indicated that, SA increased membrane 
permeability which would facilitate absorption and utilization of mineral nutrients and transport of assimilates (Gunes et al., 2005 and Aftab et al., 2010).
These results are in agreement with those obtained by Dat et al. (1998) on mustard plants and Ayat (2007) on coriander plants.

Table (8): Effect of different salicylic acid rates, salinity levels of irrigation water and their interactions on mineral and total carbohydrate contents of fennel plants during two growing seasons.

\begin{tabular}{|c|c|c|c|c|c|c|c|c|c|c|}
\hline \multirow{2}{*}{$\begin{array}{c}\text { Water } \\
\text { salinity } \\
\text { levels }\end{array}$} & \multicolumn{5}{|c|}{$2013 / 2014$} & \multicolumn{5}{|c|}{$2014 / 2015$} \\
\hline & W1 & W2 & W3 & W3 & Mean & W1 & W2 & W3 & W4 & Mean \\
\hline \multicolumn{11}{|c|}{ N (\%) } \\
\hline 0 & 2.25 & 2.21 & 2.16 & 2.10 & 2.18 & 2.30 & 2.28 & 2.22 & 2.18 & 2.24 \\
\hline 50 & 2.42 & 2.37 & 2.31 & 2.29 & 2.34 & 2.56 & 2.40 & 2.43 & 2.35 & 2.43 \\
\hline 100 & 2.89 & 2.76 & 2.52 & 2.57 & 2.68 & 3.18 & 2.84 & 2.75 & 2.66 & 2.85 \\
\hline 150 & 2.73 & 2.61 & 2.46 & 2.45 & 2.56 & 2.80 & 2.77 & 2.66 & 2.53 & 2.69 \\
\hline 200 & 2.52 & 2.44 & 2.39 & 2.33 & 2.42 & 2.58 & 2.50 & 2.49 & 2.47 & 2.51 \\
\hline Mean & 2.56 & 2.47 & 2.36 & 2.34 & & 2.68 & 2.55 & 2.51 & 2.43 & \\
\hline L.S.D. at $5 \%$ & \multicolumn{5}{|c|}{ Salinity $=0.12 S A=0.13 S$} & \multicolumn{5}{|c|}{ Salinity $=0.15$ SA $=0.17$ Salinity $\times S A=0.33$} \\
\hline \multicolumn{11}{|c|}{ P (\%) } \\
\hline 0 & 0.36 & 0.35 & 0.33 & 0.31 & 0.33 & 0.37 & 0.36 & 0.34 & 0.28 & 0.33 \\
\hline 50 & 0.42 & 0.38 & 0.39 & 0.37 & 0.39 & 0.45 & 0.41 & 0.38 & 0.39 & 0.40 \\
\hline 100 & 0.48 & 0.44 & 0.45 & 0.40 & 0.44 & 0.55 & 0.51 & 0.50 & 0.49 & 0.51 \\
\hline 150 & 0.50 & 0.49 & 0.47 & 0.46 & 0.48 & 0.53 & 0.53 & 0.50 & 0.48 & 0.51 \\
\hline 200 & 0.59 & 0.54 & 0.51 & 0.52 & 0.54 & 0.57 & 0.57 & 0.55 & 0.54 & 0.55 \\
\hline Mean & 0.47 & 0.44 & 0.43 & 0.41 & & 0.49 & 0.47 & 0.45 & 0.43 & \\
\hline L.S.D. at $5 \%$ & \multicolumn{3}{|c|}{ Salinity=NS $S A=0.14$} & Salinity $x$ & $A=0.28$ & \multicolumn{5}{|c|}{ Salinity $=$ NS $S A=0.11$ Salinity $\times S A=0.22$} \\
\hline \multicolumn{11}{|c|}{$\mathrm{K}(\%)$} \\
\hline 0 & 3.01 & 2.86 & 2.81 & 2.75 & 2.85 & 2.95 & 2.98 & 2.82 & 2.79 & 2.88 \\
\hline 50 & 3.16 & 3.08 & 2.93 & 2.89 & 3.01 & 3.21 & 3.17 & 3.05 & 3.00 & 3.10 \\
\hline 100 & 3.38 & 3.27 & 3.20 & 3.15 & 3.25 & 3.35 & 3.29 & 3.22 & 3.24 & 3.27 \\
\hline 150 & 3.82 & 3.69 & 3.44 & 3.49 & 3.61 & 3.68 & 3.57 & 3.55 & 3.40 & 3.55 \\
\hline 200 & 3.41 & 3.36 & 3.29 & 3.27 & 3.33 & 3.59 & 3.45 & 3.31 & 3.33 & 3.42 \\
\hline Mean & 3.35 & 3.25 & 3.13 & 3.11 & & 3.35 & 3.29 & 3.19 & 3.15 & \\
\hline L.S.D. at $5 \%$ & \multicolumn{5}{|c|}{ Salinity $=0.10 \quad S A=0.11$ Salinity $\times S A=0.23$} & \multicolumn{5}{|c|}{ Salinity $=0.13 \mathrm{SA}=0.14$ Salinity $\times \mathrm{SA}=0.29$} \\
\hline \multicolumn{11}{|c|}{ Total carbohydrate (\%) } \\
\hline 0 & 10.20 & 10.50 & 10.70 & 10.40 & 10.45 & 10.80 & 11.00 & 11.30 & 11.30 & 11.10 \\
\hline 50 & 11.50 & 11.80 & 11.60 & 11.20 & 11.52 & 11.40 & 11.60 & 11.90 & 11.50 & 11.60 \\
\hline 100 & 11.90 & 11.90 & 12.20 & 11.70 & 11.92 & 12.00 & 12.20 & 12.40 & 12.10 & 12.17 \\
\hline 150 & 12.00 & 12.40 & 12.10 & 11.90 & 12.10 & 12.90 & 13.20 & 13.10 & 13.10 & 13.07 \\
\hline 200 & 11.60 & 11.60 & 11.80 & 11.70 & 11.67 & 12.40 & 12.60 & 12.80 & 12.30 & 12.52 \\
\hline Mean & 11.44 & 11.64 & 11.68 & 11.38 & & 11.90 & 12.12 & 12.30 & 12.06 & \\
\hline L.S.D. at $5 \%$ & \multicolumn{3}{|c|}{ Salinity= NS } & Salinity $x$ & $A=1.18$ & \multicolumn{5}{|c|}{ Salinity $=0.30 S A=0.33$ Salinity $\times S A=0.67$} \\
\hline
\end{tabular}


For the interaction between two studied factors for both growing seasons, data revealed that, the combined treatments of plants irrigated by $\mathrm{W} 1$ level + each of 100,150 and 200 $\mathrm{mg} S A / l$ produced the highest values of $\mathrm{N}, \mathrm{K}$ and $\mathrm{P}$, respectively. Moreover, the application of water salinity at W2 level + $\mathrm{SA}$ at rate of $150 \mathrm{mg} / \mathrm{l}$ produced the highest total carbohydrate content (\%) during two seasons. These results could be supported by findings of El-Hedek (2013) on wheat plants.

\section{6- Volatile oil components:}

Data presented in Table (9) reveal that, essential oil of the produced fennel seeds in all treatments were subjected to fractionation using gas liquid chromatography (GLC). In the second season fennel oil samples appeared 11 peaks, six of them were identified ( $\alpha, \beta$ Pinene, Myrcene, $\alpha-P h e l l a n d r e n e$, Fenchone, Limonene and Anethole) and the others were unidentified.

Table (9): Effect of different salicylic acid rates, salinity levels of irrigation water and their interactions on essential oil composition of fennel plants during two growing seasons.

\begin{tabular}{|c|c|c|c|c|c|c|}
\hline \multirow{2}{*}{$\begin{array}{l}\text { Oil composition } \\
\text { Treatments }\end{array}$} & 1 & 2 & 3 & 4 & 5 & 6 \\
\hline & $\alpha-$ Pinene & Myrcene & a-Phellandrene & Fenchone & Limonene & Anethole \\
\hline \multicolumn{7}{|c|}{\begin{tabular}{|l|l|l|l|l|l|} 
Water salinity levels & & & & & \\
\end{tabular}} \\
\hline W1 & 2.25 & 1.66 & 0.62 & 18.82 & 4.47 & 69.03 \\
\hline W2 & 2.01 & 1.86 & 0.57 & 19.00 & 4.46 & 70.07 \\
\hline W3 & 1.69 & 1.56 & 0.52 & 19.05 & 3.59 & 71.56 \\
\hline W4 & 1.58 & 1.55 & 0.51 & 18.23 & 3.94 & 71.89 \\
\hline \multicolumn{7}{|l|}{ SA (mg/l) } \\
\hline 0 & 2.25 & 1.67 & 0.46 & 18.54 & 5.29 & 69.19 \\
\hline 50 & 1.94 & 1.54 & 0.52 & 19.37 & 3.94 & 70.59 \\
\hline 100 & 1.79 & 1.75 & 0.63 & 19.43 & 3.02 & 70.70 \\
\hline 150 & 1.78 & 1.55 & 0.64 & 18.80 & 4.44 & 70.93 \\
\hline 200 & 1.67 & 1.78 & 0.52 & 17.73 & 3.88 & 71.77 \\
\hline \multicolumn{7}{|l|}{ SA(mg/l) $X$ salinity levels } \\
\hline W1 & 2.75 & 1.89 & 0.53 & 17.95 & 5.64 & 67.38 \\
\hline \multirow{4}{*}{$\frac{1}{1}$} & 2.82 & 1.73 & 0.41 & 18.63 & 5.27 & 68.45 \\
\hline & 1.75 & 1.65 & 0.51 & 19.25 & 5.35 & 69.32 \\
\hline & 1.70 & 1.42 & 0.40 & 18.34 & 4.93 & 71.61 \\
\hline & 1.82 & 1.18 & 0.66 & 19.53 & 3.98 & 69.75 \\
\hline \multirow{4}{*}{$\frac{1}{1}$} & 1.91 & 1.93 & 0.53 & 19.44 & 3.73 & 70.44 \\
\hline & 1.99 & 1.65 & 0.40 & 20.29 & 3.42 & 70.52 \\
\hline & 2.04 & 1.40 & 0.49 & 18.25 & 4.65 & 71.68 \\
\hline & 1.88 & 1.58 & 0.62 & 20.53 & 3.27 & 69.29 \\
\hline \multirow[t]{4}{*}{100} & 1.91 & 1.91 & 0.74 & 19.46 & 3.80 & 70.08 \\
\hline & 1.72 & 1.70 & 0.55 & 18.85 & 2.81 & 72.15 \\
\hline & 1.65 & 1.84 & 0.63 & 18.91 & 2.22 & 71.30 \\
\hline & 2.51 & 1.80 & 0.74 & 19.34 & 4.70 & 68.26 \\
\hline \multirow[t]{4}{*}{150} & 1.84 & 2.02 & 0.66 & 19.68 & 4.59 & 70.03 \\
\hline & 1.36 & 1.15 & 0.59 & 18.75 & 3.17 & 73.64 \\
\hline & 1.41 & 1.23 & 0.60 & 17.46 & 5.30 & 71.80 \\
\hline & 2.33 & 1.85 & 0.59 & 16.77 & 4.80 & 70.47 \\
\hline \multirow{3}{*}{$\begin{array}{l}\text { W2 } \\
\text { W3 } \\
\text { W4 }\end{array}$} & 1.58 & 1.71 & 0.51 & 17.80 & 4.92 & 71.35 \\
\hline & 1.67 & 1.66 & 0.57 & 18.15 & 3.22 & 72.19 \\
\hline & 1.10 & 1.90 & 0.43 & 18.20 & 2.60 & 73.09 \\
\hline
\end{tabular}


The main compounds which characterized the essential oil of fennel plants were ( $\alpha$-Pinene, Myrcene, $\alpha-$ Phellandrene, Fenchone, Limonene and Anethole) according to Guenther (1961). The combined treatments of W2 level without SA, W2 level + $150 \mathrm{mg} / \mathrm{l} \mathrm{SA}$, W2 level+ $100 \mathrm{mg} / \mathrm{l} \mathrm{SA}$, W1 level $+100 \mathrm{mg} / \mathrm{l}$ SA, W1 level without SA, W3 level + 150 $\mathrm{mg} / \mathrm{l} \mathrm{SA}$ produced the highest values of (a-Pinene, Myrcene, a-Phellandrene, Fenchone, Limonene and Anethole), respectively. Meanwhile, the lowest enhancement on ( $\alpha$-Pinene, Myrcene, $\alpha-$ Phellandrene, Fenchone, Limonene and Anethole) were obtained by using W4 level $+200 \mathrm{mg} / \mathrm{l} \mathrm{SA}$, W3 level $+150 \mathrm{mg} / \mathrm{l}$ SA, W4 level without SA, W1 level +20 mg/l SA, W4 level + 100 mg/l SA, W1 level without $S A$, respectively during the second season.

\section{CONCLUSIONS}

Salinity of irrigation water even at moderate and high levels significantly decreased growth and biomass production of fennel plants. High salinity stress decreased the photosynthetic pigments, nutrients content and the yield of fennel. The result suggested that, salicylic acid has a great positive potential in alleviating salinity stress on plant growth, especially at rate of 150 $\mathrm{mg} / \mathrm{l}$.

\section{REFERENCES}

Abdul-Qados, A.M.S. (2015). Effects of salicylic acid on growth, yield and chemical contents of pepper (Capsicum annuum, L.) plants grown under salt stress conditions. Int. J. Agri. Crop Sci., 8 (2): 107-113.

Abou El-Nour, W.M.G. (2013). Studies on soils irrigated with ground water in Menoufia Governorate. M. Sc. Thesis, Fac. of Agric., Menoufia Univ., Egypt.

Abu-Zeid, M. (1999). Egypt's Water Policy for the $21^{\text {st }}$ Century, $7^{\text {th }}$ Nile 2002 , Conference, March 15-19, 1999, Cairo, Egypt.
Aftab, T., M.M.A. Khan, M. Idrees, M. Naeem and M. Moinuddin (2010). Salicylic acid acts as potent enhancer of growth, photosynthesis and artemisinin production in Artemisia annua L. J. Crop Sci. Biotech., 13 (3): 183-188.

Akça, Y. and E. Samsunlu (2012). The effect of salt stress on growth, chlorophyll content, proline and nutrient accumulation, and $\mathrm{K} / \mathrm{Na}$ ratio in walnut. Pak. J. Bot., 44: 1513-1520.

Ali, E.F., S.A. Bazaid and F.A. Hassan (2014). Salinity tolerance of taif roses by gibberellic acid $\left(G_{3}\right)$. International Journal of Science and Research, 3 (11): 184-192.

Ali, A.F., E.A. Hassan, E.H.A. Hamad and A.A.M. Ahmed (2016). Growth and productivity of Ammi visnaga as affected by organic fertilizers rate and antioxidants level. Middle East $J$. Agric. Res., 5(4): 620-628.

Al-Qubaie, A.I. (2013). Response Jasminum sambac ait plants to spraying salicylic acid. Met., Env. \& Arid Land Agric. Sci., 24(1): 67-73.

Ayat, A. (2007). Effect of fertilization with macro, micro nutrients and antioxidants on coriander (Coriandrum sativum, L.) plants grown in new reclaimed land. $M$. Sc. Thesis, Fac. of Agric., Minia Univ., Egypt.

Barbara, F.R. and L.J. Brain (1994). "Minitab Hand Book". duxbury press. an imprint of wad sworth publish . Comp., Belonont, California.

British Pharmacopea (1963). "Determination of Volatile Oil in Drugs". The Pharmaceutical Press, London.

Caia, X., G. Niub, T. Starman and C. Hall (2014). Response of six garden roses (Rosa $\times$ hybrida L.) to salt stress. Scientia Horticulturae, 168: 27-32.

Chapman, H.D. and P.F. Pratt (1982). "Methods of Plant Analysis. I. Methods of Anaylsis for Soil, Plant 
and Water". Chapman Publishers, Riverside, California, USA.

Chartzoulakis, K. and G. Klapaki (2000). Response of two green house pepper hybrids to $\mathrm{NaCl}$ salinity during different growth stages. Sci. Scientia Horticulturae, 86: 247-260.

Choi, E. and J. Hwang (2004). Antiinflammatory, analgesic and antioxidant activities of the fruit of Foeniculum vulgare. Fitoterapia, 75 (6): 557-565.

Cottenie, A., M. Verloo, L. Kiekens, G. Velghe and R. Camerlynck (1982). "Chemical Analysis of Plants and Soils". Lab. Analytical and Agrochem, State Univ., Ghent-Belgium.

Dat, J.F., C.H. Foyer and I.M. Scott (1998). Changes in salicylic acid and antioxidants during induced thermo tolerance in mustard seedlings. Plant Physiol., 118: 1455-1461.

De Lacerda, C.F., J. Cambraia, M.A. Oliva, H.A. Ruiz and J.T. Prisco (2003). Solute accumulation and distribution during shoot and leaf development in two sorghum genotypes under salt stress. Environ. Exp. Bot., 49: 107-120.

Delgado, M. J., F. Ligero and C. Lluch (1994). Effects of salt stress on growth and nitrogen fixation by pea, fababean, common bean and soybean plants. Soil. Biol. Biochem., 26, 371376.

Dubois, M., K.A. Gilles, J.K. Hamilton, P.A. Robers and F. Smith (1956). Calorimetric method for determination of sugars and related substance. Anal. Chem., 28; 350-356.

Eid, R.A., L.S. Taha and S.M.M. Ibrahiem (2011). Alleviation of adverse effects of salinity on growth and chemical constituents of marigold plants by using glutathione and ascorbate. Journal of Applied Sciences Research, 7(5): 714-721.

El-Hedek, K. S. (2013). Effect of foliar applications of salicylic acid and potassium silicate on tolerance of wheat plants to soil salinity. J. Soil Sci. and Agric. Eng., Mansoura Univ. 4 (3): 335 - 357.

Fayez, K.A. and S.A. Bazaid (2014). Improving drought and salinity tolerance in barley by application of salicylic acid and potassium nitrate. Journal of the Saudi Society of Agricultural Sciences, 13: 45-55.

Gharib, F. (2006). Effect of salicylic acid on the growth, metabolic activities and oil content of basil and marjoram. International Journal of Agriculture and Biology, 4: 485-492.

Guenther, E. (1961). "The Essential Oils". Vo1. IV. Van Nostrand Comp. Inc. New York. P. 645.

Gunes, A., A. Inal, M. Alpaslan, N. Cicek, E. Guneri, F. Eraslan and T. Guzelordu (2005). Effects of exogenously applied salicylic acid on the induction of multiple stress tolerance and mineral nutrition in maize (Zea mays, L.). Arch. Agron. Soil Sci., 51 (6): 687-695.

Hashish, K.I., R.A. Eid, M.M. Kandil and A.A.M. Mazher (2015). Study on various level of salinity on some morphological and chemical composition of gladiolus plants by foliar spray with glutathione and thiamine. Int. J. Chem. Tech. Res., 8(9): 334-344.

Hassan, F.A.S. and E. Ali (2014). Effects of salt stress on growth, antioxidant enzyme activity and some other physiological parameters in jojoba [Simmondsia chinensis (Link) Schneider] plant. Australian journal of crop science, 8(12):1615-1624.

Hassan, F.A.S., M.M. Morsi and N.G.S. Aljoudi (2017). Alleviating the adverse effects of salt stress in rosemary by salicylic acid treatment. Research Journal of Pharmaceutical, Biological and Chemical Sciences, 8(3):19801995.

He, Y.L., Y.L. Liu, Q. Chen and A.H. Bian (2002). Thermo tolerance related to antioxidation induced by salicylic acid 
and heat hardening in tall fescue seedlings. J. Plant Physiol. Mol. Biol., 28: 89-95.

Kabiri, R., F. Nasibi and H. Farahbakhsh (2014). Effect of exogenous salicylic acid on some physiological parameters and alleviation of drought stress in Nigella sativa plant under hydroponic culture. Plant Protection Science J., 50 (1): 43-51.

Karlidag, H., E. Yildirim and M. Turan (2009). Salicylic acid ameliorates the adverse effect of salt stress strewberry. Scientia Agricola Journal, 66 (2): 180-187.

Khalid, A.K. and M.R. Shedeed (2014). The effects of saline irrigation water and cobalt on growth and chemical composition in Nigella sativa. Nusantara, 6 (2): 146-151.

Khan, M.A., M.Z. Ahmed and A. Hameed (2006). Effect of sea salt and Lascorbic acid on the seed germination of halophytes. J Aird Environ., 67: 535-540.

Khan, W., B. Prithiviraj and D.L. Smith (2003). Photosynthetic responses of corn and soybean to foliar application of salicylates. J. Plant Physiol., 160: 485-492.

Kim, H. T. (1996). "Soil Sampling, Preparation and Analysis". Marcel Dekker Inc., New York, p. 391.

Klessig, D.F. and J. Malamy (1994). The salicylic acid signal in plants. Plant Mol Biol., 26: 1439-1458.

Munns, R. (2002). Comparative physiology of salt and water stress. Plant Cell Environ., 25:239-250.

Munns, R. (2005). Genes and salt tolerance: bringing them together. New Phytol., 167:645-663.

Page, A.L., R.H. Miller and D.R. Keeney (1982). "Methods of Soil Analysis". II. Chemical and Microbiogical Properties. $\quad 2^{\text {nd }}$ Ed. Madison, Wisconsin , U. S. A.

Rahimi, R., A. Mohammakhani, V. Roohi and N. Armand (2012). Effects of salt stress on the yield components, essential oil content and cholorophyll concentration of the three fennel populations. Intl. j. Agron., 3(S):716720.

Rahimi, R. and M.R. Ardekani (2013). Medicinal properties of Foeniculum valgare Mill. In traditional Iranian medicine and modern phototherapy. Chin J. inteqr Med., 19(1): 73-79.

Simon, J.E., D.R. Bubenheim, R.J. Joly and D.J. Charles (1992). Water stress induced alterations in essential oil content and composition of sweet basil. J. Essent Oil Res., 4 :71-75.

Singh, B. and K. Usha (2003). Salicylic acid induced physiological and biochemical changes in wheat seedlings under water stress. Plant Growth Regulation, 39: 137-141.

Singh, G., S. Maurya, M.P. De Lampasona and C. Catalan (2006). Chemical constituents, antifungal and ant oxidative potential of Foeniculum vulgare volatile oil and its acetone extract. Food Control, 17: 745-752.

Witham, F.H., D.F. Blaydes and P. M. Devlin (1971). Experiments in Plant Physiology. PP.55-58 Van Nosland Reinhold Co., New York.

Yu, X., C. Liang, J. Chen, X. Qi, Y. Liu and $W$. Li (2015). The effects of salinity stress on morphological characteristics, mineral nutrient accumulation and essential oil yield and composition in Mentha Canadensis L. Scientia Horticulturae, 197: 579-583.

Zhu, J. K. (2001). Plant salt tolerance. Trends Plant Sci., 6: 66-71.

Ziaf, K., M. Amjad, M.A. Pervez, Q. Iqbal, I.A. Rajwana and M. Ayub (2009). Evaluation of different growth and physiological traits as indices of salt tolerance in hot pepper (Capsicum annuum L.). Pakistan J. Bot., 41: 1797-1809. 


\section{تأثير إضافة حامض السلسليك علي النمو و المكونات النشطة لنبات الثمر تحت ظروف الإجهاد الملحي}

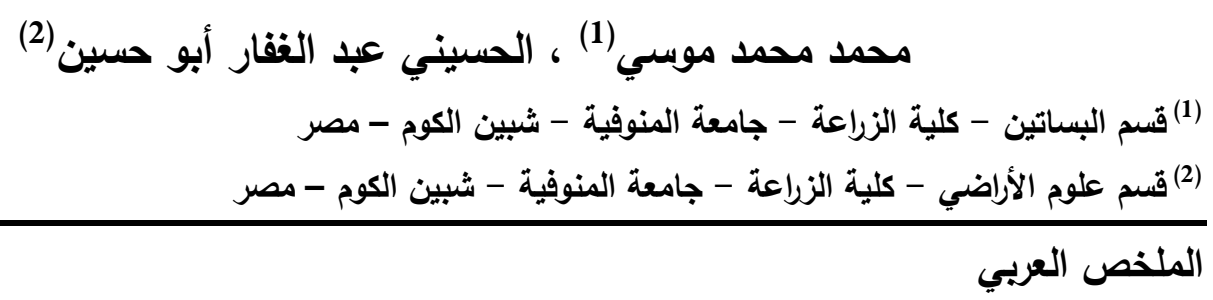

في هذه الآونة تواجه مصر مشكلة في كميات مياه الري و ذلك لثبات حصة مصر المائية، ولهذا فإن الخطوة الرئيسية في

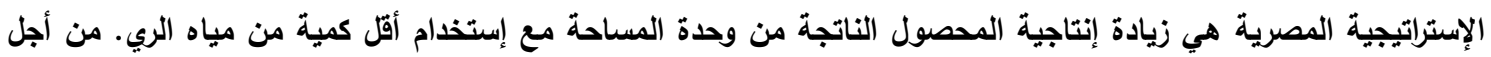

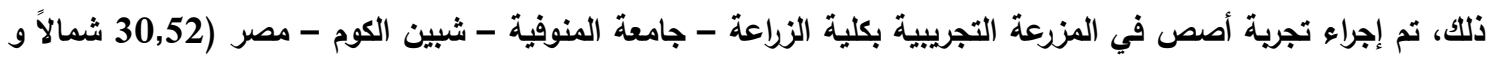
30,99 شرقاً ) وذلك خلال موسمي نمو شتاء متتاليين : 2014/2013 و 2015/2014 لدراسة التأثير الفردي و المشترك لكلٍ من حامض السلسليك و ملوحة مياه الري علي النمو و المحصول و المكونات الكيميائية لنبات الثمر النامي في أرض ذات

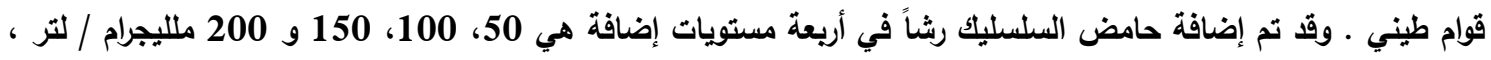
وذلك بالإضافة إلي معاملة الكنترول التي إستُخدم فيها الماء بدون حامض السلسليك. و كانت مياه الري المستخدمه (مياه

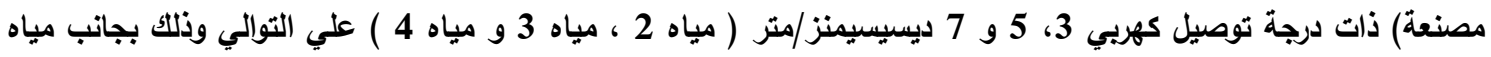
النيل (مياه1) التي تميزت بدرجة توصيل كهربي ومثلت كل معامله بثلاث مكرات .

في كلٍ من موسمي النمو، تم تسجيل صفات النمو الخضري للنبات مثل طول النبات (سم) ، عدات الأفرع الرئيسية لكل نبات

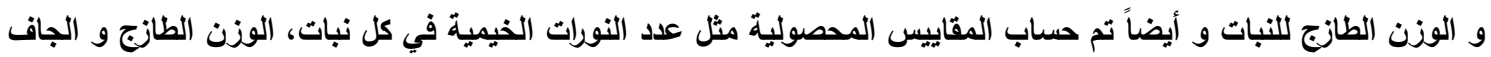

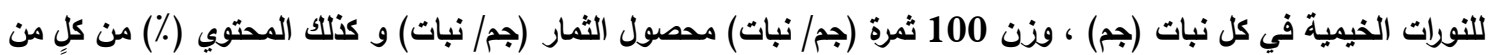
الزيت الطيار، مكونات الزيت، صبغات البناء الضوئي ، النيتروجين ، الفوسفور ، البوتاسيوم وأيضاً المحتوي الكلي للكريوهيدرات

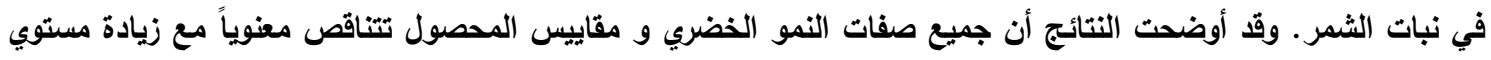
ملوحة مياه الري، بإستثناء الري بمياه 2 التي صاحبها زيادة بسيطة في كل المقاييس المدروسة. كما أن محتوي الكلوروفيل أ ،

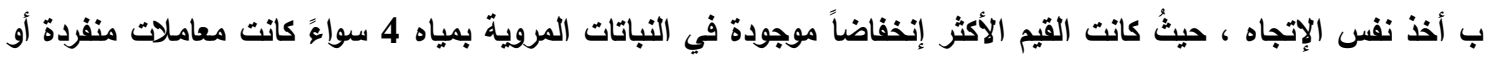

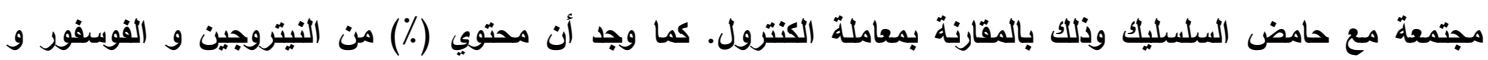
البوتاسيوم يتناقص بزيادة مستوي ملوحة مياه الري ، بينما محتوي الكاروتيندات و الزيت الطيار و الكربوهيدرات الكلية يتزايد تدريجياً مع زيادة ملوحة مياه الري و خاصة عذد الري بمياه 3 ـ الرش بحامض السلسليك بمختلف التركيزات يُخفف من التأثير

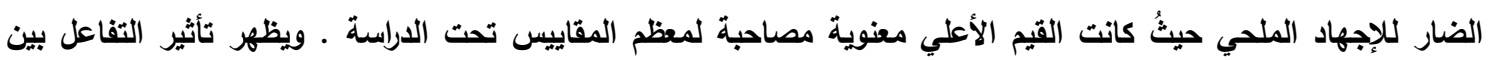
مستويات ملوحة مياه الري و تركيزات حامض السلسليك علي معظم مقاييس النمو و المحصول و خاصة عند ري نباتات الثمر

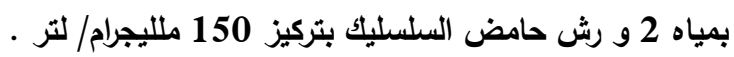

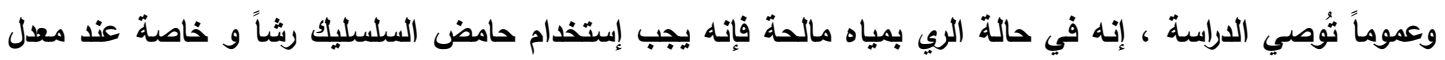
150 ملليجرام/ لتر وذلك للتخفيف من التأثيرات الضارة لملوحة مياه الري علي كلٍ من كمية و جودة نباتات الثمر .

أسماء السادة المحكمين

أ.د/ على عبدالحميد عوض كلية الزراعة - جامعة الزقازيق ،أ.د/ مجدى رابح محمد رابح كلية الزراعة - جامعة المنوفية 
